IJLR: International Journal of Law Recontruction

Volume 4, Number 1, April 2020

DOI : $10.26532 /$ ijlr.v4i1.9680

\title{
STRENGTHENING THE LAW IN ORDER TO KEEP EXISTENCE THE UNITARY STATE OF THE REPUBLIC OF INDONESIA
}

\author{
Rakhmat Bowo Suharto \\ Sultan Agung Islamic University \\ rakhmat@unissula.ac.id
}

\begin{abstract}
The Unitary State of the Republic of Indonesia (NKRI) was founded on the support of diversity, both ethnicity, religion, and customs. As historical, the building of such a nation could not be separated from the various tests, beginning of rebellions based on ethnicity, religion, and political ideology, to replace the form of a union state with the enactment of the Constitution. RIS has also occurred. In fact, the Republic of Indonesia remained standing up to this moment. As a law that addresses the entire existing local legal system, Indonesian legal system has actually placed various means integration which is at the same time the national identity of the Republic of Indonesia building. Associated with the goal of the existence of the Republic of Indonesia, the existing legal construction needs to be strengthened by conducting $a$ paradigmatic evaluation that is continuous and continuous related to: (1) legal pluralism policy; (2) legalistic legal paradigm; (3) Central and Regional Relations and local communities; (4) Cultivation of cultural aspects and social capital in development policies; (5) the division of public and private space related to the expression of differences between various cultural, religious or ethnic communities; and (6) Liberalization of political life.
\end{abstract}

Keywords: Nationality; The existence of the Republic of Indonesia; Strengthening the Law.

\section{A. INTRODUCTION}

As is widely known, the Unitary State of the Republic of Indonesia (NKRI) was founded on the support of diversity, both ethnicity, religion, and customs of the citizens who inhabit it. Such a social setting is the background of the struggle for the desire to achieve the ideals of an independent nation. Theoretically, nationalism is motivated by the belief that the political community that can be expected to have the ability to guarantee the welfare, safety and survival of people in the world (which is full of competition) is only a political community that can uphold and successfully integrate local units with the same identity. ${ }^{1}$ In line with this explanation, the big problem faced by the pioneers of independence and the founder of the country at that time was how to build a national life on the basis of socio-cultural diversity rooted in substructures called tribes, ethnic groups, or other collective units both cultural and religious.

1 Soetandyo Wignjosoebroto, Hukum Paradigma, Metode dan Dinamika Masalahnya, Lembaga Studi dan Advokasi Masyarakat (ELSAM) dan Perkumpulan untuk Pembaharuan Hukum Berbasis Masyarakat dan Ekologi (HuMa), Jakarta, P. 545-546. 
Thus it is easy to understand why the initial obsession of the founding fathers of this country struggled with the efforts around how to build unity upon diversity in a new national identity of Indonesia. The history of Indonesian constitution records that efforts to establish unity in diversity actually occurred long before the independence period. In the Majapahit era, for example, coexistence in diversity situations was accepted as normal, and this was reflected in the expression of MPU Tantular in his book Sutasoma, namely: "Unity in Diversity tan Hana Dharma Mangrwa", different but one, there is no ambiguous religion. During the period of movement, the use of a new Indonesian identity began to show its seeds since the founding of Indische Vereeniging which in 1922 changed its name to Indonesische Vereeniging, and finally in 1924 it was changed to the Indonesian Association. The political ideology of the Indonesian Association is Indonesian independence which requires four principles, namely national unity, solidarity, non-cooperation, and independence.

After that, an important milestone was the holding of the Second Indonesian Youth Congress which was held on October 26-28, 1928 which pledged the Youth Pledge to be one-watered, one-nationed and one-language, namely Indonesia. In the preparatory periods for independence, the national commitment was noted from the discussions that emerged at the BPUPKI sessions. The spirit of unity is at least reflected in the composition of the BPUPKI membership, which more or less represented the diversity of elements of Indonesian nationality at that time. ${ }^{2}$ The important thing that reflects how the founders of this country has a high national spirit, that is, almost all members of BPUPKI when convening to formulate the basis of the state and constitution, emphasize the importance of unity as the foundation for the establishment of an independent Indonesian state. ${ }^{3}$

In Soekarno's view, the building of Indonesian nationality was a broad nationality which he called a "nationale staat". The national building is not only put together because of the similarity of history as a nation that was colonized, but also because of the desire to unite. ${ }^{4}$ To form Indonesia's "nationale staat", the desire to unite and the similarity of history is not enough. It takes a unity about the view of life as the basis of nationality, geopolitical unity that shows the territory of the nation state, unity of citizens of each population, unity of government that organizes national government, cultural unity, language, national symbols, and the national anthem as national identity.

The concept of nationality which has been formally juridically formalized in the Basic of the State and the State Constitution, apparently cannot be separated from the test. Starting from rebellions based on ethnicity, religion, and political ideology, this nation has experienced. Even through the juridical route that changed the form of the state and the system of government with the enactment of the RIS Constitution had also occurred. In fact, the Republic of Indonesia remained standing up to this moment. It cannot be separated

\footnotetext{
2 Ibid.,

3 Yudi Latif, Negara Paripurna, Historisitas, Rasionalitas, dan Aktualitas Pancasila, Gramedia Pustaka Utama, Jakarta, P. 328-331.

4 Soetandyo Wignjosoebroto, Op., Cit, hlm.
} 
from the strong commitment of this nation in upholding unity for the sake of maintaining the national home of Indonesia. However, the recent national social and political developments that have caused some concern. The strengthening of tribal or religious solidarity that arises in the implementation of elections in the area, for example, or the emergence of understandings that are not in line with the Republic of Indonesia is feared can be a trigger for social rifts that can threaten the unity of the nation and the existence of the Republic of Indonesia.

In the case of Indonesia, although unity departs from the desires / willingness of Indonesian people who come from ethnic, cultural, and religious diversity, this desire leads to efforts to place the state as a unifying element. It is this country that is given the mandate to maintain and manage the unity with the power of legitimized by law. Thus, state politics for Indonesia becomes important to maintain the integrity and sustainability of the nation, and that means placing the law as an important instrument to maintain the existence of the Republic of Indonesia. Related to the social and political situation as mentioned earlier, the question is how to strengthen the law in order to maintain the existence of the Republic of Indonesia? The question is not intended to illustrate that law is the only instrument that can be utilized to manage national unity and deny other social and political instruments, but is solely intended to determine the limits of the study in this paper, which limits itself to the analysis of strengthening the legal role in maintaining the existence of the Republic of Indonesia.

\section{B. DISCUSSION}

\section{The Role of Law as an Instrument of Integration in a Nation State}

The need for a national legal system is a necessity when life in a pluralistic society is developing from local community units to the level of national life organized as a political community called the nation state. It requires a single legal system, namely the national legal system which is a reference for the implementation of social, political, and cultural life for all residents of the nation state. According to Hans Kelsen, in traditional optics, it is not possible to understand the essence of a national legal system, namely its principium individuationis, unless the State is postulated as a fundamental social reality. The norm system has unity and uniqueness so that it is appropriate to be called a national legal system solely because the norm system is related according to one way or another with one State as a real social fact, because this norm system was created by one State or the norm system is valid for one country. ${ }^{5}$

As a newly independent nation state, the national legal system was established after the declaration of Indonesian Nation's Independence on August 17, 1945. Through the declaration of independence, it meant that the Indonesian people had broken ties with the previous legal system, namely the Dutch East Indies and Japanese occupation. Thus, the

5 Hans Kelsen, Teori Umum Hukum dan Negara, Dasar-dasar Ilmu Hukum Normatif Sebagai IImu Hukum Deskriptif_Empirik, alih Bahaasa oleh Drs. Somardi, Bee Media Indonesia, Jakarta, 2007, P. 226. 
Proclamation of Independence is the first norm that makes the Indonesian nation state as an organization of power having sovereignty and authority to regulate and stipulate laws that would be a reference for state administration. ${ }^{6}$

As a law that overcomes the entire existing local legal system, the Indonesian legal system has put in place various means of integration which are at the same time a national identity that supports pluralism in the Unitary Republic of Indonesia.. ${ }^{7}$ The first is that the concept of nationalism, which is based on the desire to unite under the auspices of history as a colonized nation, can be explicitly embodied in the formulation of the Jakarta Charter which was later revealed in the Opening of the 1945 Constitution. Weltanschauung, is a shared life that unites all elements of individuals and groups as a national foundation. ${ }^{8}$ Thus, the second is that the law has also determined the unity of a view of life called the Pancasila which is contained in the Fourth Preamble of the 1945 Constitution.

Third is the affirmation of the unity of Indonesia in the form of the unity of the islands from Sabang to Merauke which forms a single regional unit. Regarding this matter, the formula of the 1945 Constitution was not found. Regarding territorial integrity, through the Juanda Declaration of 13 December 1957 the Government of the Republic of Indonesia was able to affirm claims about the concept of an island nation which was later recognized by the United Nations through the 2nd United Nations Convention on the Law of the Sea (UNCLOS). After that, the territory of the Indonesian state was included in the constitution after the 1945 Constitution was amended, and through Article 25A of the 1945 Constitution of the State of the Republic of Indonesia it was emphasized that the Unitary State of the Republic of Indonesia was an archipelago characterized by an archipelago with territorial borders and rights. their rights are determined by law. Based on this provision, Law Number 43 of 2008 concerning State Territories was born.

Fourth, the assertion of Indonesian citizenship is set out in Article 26 paragraph (1) of the Constitution of 1945 which states: "Citizens are indigenous peoples and are lawful citizens of other nationalities". Subsequently in paragraph (2) it is stated that the requirements regarding the State's honor are governed by law. In connection with this mandate, in 1958 the Law No. 62 of 1958 on Citizenship, which in 1976 amended its Article 18 by Law No. 3 of 1976 on Amendment of Article 18 of Law No. 62 1958 on Citizenship. This law later in the era of reform was repealed and replaced by Law No. 12 of 2006 on Citizenship.

Fifth, is the form of state and system of government affirmed in Article 1 paragraph (1) of the 1945 Constitution which reads: "The State of Indonesia is a Unitary State in the form of a Republic". In the form of unity, state power is divided between the central government and regional

6 Joeniarto, Sejarah Ketatanegaraan Republik Indonesia, Yayasan Badan Penerbit Gadjah Mada, Yogyakarta, 1966, P. 6-7.

7 Hans Kelsen, Op Cit, P. 229-230

8 Yudi Latif, Loc. Cit., P. 331. 
governments. The choice of the form of the Unitary State has the consequence of the existence of the Regional Government through Article 18 , which was formed to carry out government affairs which are submitted by the Center to be its authority. In the context of the unitary state, the state recognizes and respects special or special regional government units that are regulated by law. In addition, the State also recognizes and respects the customary law community units along with their traditional rights as long as they are still alive and in accordance with the development of society and the principles of the Unitary State of the Republic of Indonesia, which is regulated by law. From these provisions, it is evident that in a unitary state it is impossible to have units that stand like states that have their own sovereignty. Unity under the state, is part of the Government of the State whose existence must be in line with the existence of the Unitary Republic of Indonesia.

Sixth, related to unity in national culture, is formulated into the provisions of Article 32 of the 1945 Constitution which reads quite simply, namely: "The government promotes Indonesian national culture". Even though this was briefly conveyed, the meaning it contained seemed to try to find a middle ground of various opinions that developed among BPUPKI members at the time of the formulation of the article. This can be seen from the Elucidation of Article 32, which basically reads that the culture of the nation is what arises as the effort of the people of Indonesia themselves. The old and original culture which is found as the cultural peaks in regions throughout Indonesia is counted as the nation's culture. Cultural efforts must lead to the advancement of civilization, culture, and unity by not rejecting new materials from foreign cultures that can develop and enrich one's own life and enhance the degree of Indonesian humanity.

Seventh, other means of unifying Indonesian nationalities are flags, languages, national symbols, and national anthems. In the 1945 Constitution, the unifying means is only regulated regarding the state flag stipulated in Article 35 and the state language stipulated in Article 36. However, after the 1945 Constitution has been amended, the regulation regarding the unifying means is complemented by a regulation regarding the state emblem which in Article 36A affirms that the Symbol The country is Garuda Pancasila with the motto Unity in Diversity, and the national anthem in Article 36B which reads: "The National Anthem is Greater Indonesia". Regarding the language, flag, national emblem and national anthem, Law No. 24 of 2009 concerning Flags, Languages and Symbols of the Country, as well as the National Anthem. In part considering the letter a of the law it is stated that the flag, language and symbol of the state, as well as the Indonesian national anthem are a means of unifying, identifying, and manifesting the existence of the nation which are symbols of national sovereignty and honor.

Various legal provisions both in the realm of the constitution and legislation as explained above, show that through the establishment of its norms, the law functions as a unifying means for integrating ethnic, cultural, and religious diversity into Indonesian national identity in the Republic of 
Indonesia's territory and maintaining and ensuring its preservation that union. The national design constructed by the National legal system, shows that unity in the concept of Indonesian nationhood is not an attempt to equalize or kill local identity as reflected by the diversity of cultural, religious and ethnic aspects, but to build a sense of nationality that can arouse its nationalistic sentiments that drive an intention and the people's conviction as one group, one nation. ${ }^{9}$

Thus, the basis of Indonesian nationality will be the knot of unity, capable of expressing unity in diversity, and diversity in unity, which in the state slogan is stated by the phrase "Bhinneka Tunggal Ika". ${ }^{10}$ Thus, the thing that underlies the existence of the Indonesian nation is none other than political ideals to bring a country that can bring together values, interests, and ideals together. Although culture plays an important role in national unity, the main key that unites this nation is not the similarity of culture, religion, and ethnicity, but because of the Unitary Republic of Indonesia which accommodates shared political ideals, overcomes all group and individual understandings. ${ }^{11}$

\section{Strengthening the Role of Law in the Context of Maintaining the Existence of the Unitary State of the Republic of Indonesia}

In line with the theoretical concept as conveyed by Ernest Renan and Otto Bauer that has been stated earlier, the existence of the NKRI as a nation state will only be established, especially when the unity among citizens remains maintained. This is also what was said by most BPUPKI members such as Soekarno, Muh. Yamin, Sosrodinigrat, Woerjaningrat, Soesanto Tirtoprodjo, Ki Bagoes Hadikoesoemo. By referring to the various opinions that developed in discussions on the formulation of Pancasila and the basis of the State in the BPUPKI sessions, unity in the plurality of Indonesian national homes, can only be maintained if:

a. There is a binding on the citizens of the nation to become one soul, namely the will to live together. This is because what is referred to as a nation, can be realized as an expression of equality of character that grows because of unity of experience.

b. There is mutual cooperation among the citizens of the nation;

c. To encourage the spirit of mutual cooperation, the state must be able to protect the entire nation and the whole of Indonesia's blood spill, and provide a common good for its citizens regardless of class, ethnicity, or religion;

d. The state continuously organizes and develops civic and multiculturalism education that can build a sense of togetherness;

e. The state must guarantee a more participatory and nondiscriminatory public life;

f. There is citizen loyalty to a set of political and institutional ideals that are considered fair and effective;

9 Yudi Latif, Loc. Cit., hlm. 370.

10 Ibid.

11 Ibid. 
g. The state must be able to realize justice and shared prosperity;

h. The state must be able to guarantee equality of opportunity and social interaction.

In the Islamic concept, the unity of a social entity can meet its end (extinction) due to three main reasons, namely: (1) the void of justice and the spread of tyranny; (2) lack of social control; and (3) fragmentation. ${ }^{12}$

If the various prerequisites are narrated in unity, then it can be formulated as follows: "Unity in the plurality of the Republic of Indonesia can only be maintained when the state is able to protect all nations and territorial territories, creating public life that guarantees equality and active participation in state management, able to realize justice and prosperity and the common good without discrimination, and conduct citizenship education and multiculturalism. If this is able to be carried out by the state consistently, the sense of togetherness of citizens will grow, so that they mutually cooperate and rise in confidence in the country so that the loyalty of citizens to the ideals of the Republic of Indonesia is maintained along with increased active participation of citizens in the administration of government ".

The question is, do the legal norms that currently exist do not regulate the above matters, so that various social and political dynamics that threaten unity remain to emerge? If we look closely at the various provisions in national legislation, the answer is that the above have been regulated, which can be said to be sufficient from the aspect of norms. Associated with the aim of maintaining unity in the context of maintaining the existence of the Unitary Republic of Indonesia, the existing legal construction needs to be strengthened by conducting paradigmatic evaluations as material for implementing legal reform that is continuous and sustainable. The evaluation is related to:

a. In countries that are culturally diverse but united in a nationalist container, the existence of national law that manifests political nationalism, always faces the problem of pluralism of local laws which always manifests loyalty to local values and needs. Experience has proven that attempts to reconcile the content of national law with local law often have difficulties. What often happens is the tendency to disregard plural local law to prioritize national law. If you pay attention to the provisions of the 1945 Constitution of the Republic of Indonesia Article 18B paragraph (2) clearly reflects the policy of strong legal pluralism that is legalistic. This is where the importance of Indonesia's legal pluralism policy needs to be carried out to a certain extent due to the legalistic recognition of local laws before national law.Dalam konsep nation state, what is called law is definitely intended to refer to positive law. ${ }^{13}$ Theoretically, legal positivation is often laden with conflicts of interest which in the end

12 Muchlis Muhammad Hanafi et al, TafsirMaudhu'T (Tafsir Al-Qur'an Tematik; Al-Qur'an dan Kebhinekaan, P.T. Lentera Ilmu Makrifat, 2019, P. 42.

13 Soetandyo Wignjosoebroto, Loc. Cit., P. 350 
usually reflect political alignments and are not too sensitive to justice issues. Such a paradigm is of course often unfavorable when dealing with facts of local law that are not posivated, let alone not by the bearers of state power. Such a paradigm needs attention to be corrected immediately, especially in the process of forming and implementing it which should prioritize affirmations about the values of justice.

b. In a unitary state, there is stratification between the Central Government which has sovereignty, and the Regional Government which is a sub-national government unit. In addition, according to Article 18B of the 1945 Constitution of the Republic of Indonesia, it also recognizes special or special regional government units and traditional law community units along with their traditional rights. On behalf of unity, local government and customary law community units sometimes become confined to aspiration and thus become less helpless. If we look closely at each law governing regional government, the regulation of central and regional relations does not seem to have reached the final form in line with the maintenance of unity while giving appreciation and empowerment to the region.

c. Development policies within the framework of achieving state goals often forget to work on software aspects that are components of the nation state, such as culture and social capital. In fact, the values of wisdom possessed by local communities in their culture are extremely important to carry out the law which is full of moral considerations. Evidence that attention to cultural values is still lacking, laws governing culture only existed and were passed in 2017, even though the provisions regarding the Government's obligation to advance national culture have existed since the 1945 Constitution was passed. Likewise, social capital (social capital), development practices almost always highlight the achievements of economic prosperity because it is believed to provide major support for the progress of other fields, has resulted in the decline of social capital (social capital) which is a determining factor for success in development. Francis Fukuyama, social capital is a set of informal values or norms that are shared between members of a group that allows for cooperation between them.. ${ }^{14}$ As a social reality, social capital is a resource that can be seen as an investment to get new resources. This social capital is contained in social interactions, and is an attribute of a social structure. Because of its nature, the appearance of social capital is more difficult to grasp, even though its functionality is easily felt. According to Jousairi Hasbullah, the core of social capital research lies in how the community's ability in an entity or group to work together to build a network to achieve common goals. ${ }^{15}$

14 Francis Fukuyama, The Great Disruption, Hakikat Manusia dan Rekonstruksi Tatanan Sosial, Dialihbahasakan oleh Ruslani, Qalam Press, Yogyakarta, 2002, P, 22.

15 Jousairi Hasbullah, Social Capital (Menuju Keunggulan Budaya Manusia Indonesia), MRUnited Press, Jakarta, 2006, P. 9. 
d. Pluralism in the Republic of Indonesia is a fact of Indonesian nationality. With pluralism there must be values, beliefs, or things that are the same, relatively the same, even completely different between communities of culture, religion, and ethnicity. The country's founders agreed that differences in matters of culture, religion and ethnicity were part of the nation's wealth and remained protected and respected. The unity of the nation is not cultural, religious and ethnic similarity, but rather because of a Unity state which holds shared political ideals. Looking at the recent social and political dynamics, one source of the trigger is the incompleteness of this nation dividing public and private space related to differences between various cultural, religious or ethnic communities. It is necessary to have policies that can provide little certainty about how these differences are placed in discourse or social relations. At the very least, there are restrictions on openly discussing or campaigning on matters that differ principally in relation to religious, cultural or ethnic issues when they are intended as values that will become a guideline for the implementation or fulfillment of human rights.

e. Liberalization of political life has more or less brought rational thoughts, filled with economic considerations, and pragmatically in achieving the goals of power. The impact, the values of wisdom, statesmanship, honesty, often do not become the motivation behind the actions and behavior of citizens in social and political relations. As a result, the masses are easily brought into conflict by elite interests, or conflicts of interest between citizens or between groups that sometimes erupt into open and anarchist conflicts, largely due to something trivial.

\section{CONSLUSION}

What is described above illustrates that Indonesian nationality will become a knot of unity, capable of expressing unity in diversity, and diversity in unity, which in the state slogan is stated by the phrase " Bhinneka Tunggal Ika". Thus, the thing that underlies the existence of the Indonesian nation is none other than political ideals to bring a country that can bring together values, interests, and ideals together. The main key that can unite this nation is not the similarity of culture, religion, and ethnicity, but because of the existence of the Unitary Republic of Indonesia which accommodates shared political ideals, overcomes all group and individual understandings.

As a legal system that overcomes the entire existing local legal system, the Indonesian legal system has put in place various means of integration which are at the same time a national identity that supports diversity in the Unitary Republic of Indonesia. The law has played an important role so that the existence of the Homeland is maintained from disunity. Unity in the diversity of the Indonesian nation state embodied in the Republic of Indonesia can only be maintained when the state is able to protect all nations and territorial territories, create public life that guarantees 
equality and active participation in state management, is able to realize justice and prosperity and the common good without discrimination, and organizes education citizenship and multiculturalism. If the state is able to do it consistently, then the sense of togetherness of citizens will grow, so that they mutually cooperate and rise in confidence in the country so that the loyalty of citizens to the ideals of the Republic of Indonesia is maintained along with increased active participation of citizens in the administration of government.

\section{BIBLIOGRAPHY}

Francis Fukuyama, The Great Disruption, Hakikat Manusia dan Rekonstruksi Tatanan Sosial, Dialihbahasakan oleh Ruslani, Qalam Press, Yogyakarta, 2002.

Hans Kelsen, dalam Teori Umum Hukum dan Negara, alih bahasa oleh Soemardi, Bee Media Indonesia, Jakarta, 2007.

Joeniarto, Sejarah Ketatanegaraan Republik Indonesia, Yayasan Badan Penerbit Gadjah Mada, Yogyakarta, 1966.

Jousairi Hasbullah, Social Capital (Menuju Keunggulan Budaya Manusia Indonesia), MR-United Press, Jakarta, 2006.

Muchlis Muhammad Hanafi et al, TafsirMaudhu'I (Tafsir Al-Qur'an Tematik; AlQur'an danKebhinekaan, P.T. LenteraIlmuMakrifat, 2019.

Muhtar Said dalam Mengulas Kembali Negara Integralistik, dalam Soepomo: Perg ulatan Tafsir Negara Integralistik, Penerbit Th afa Media, Yogyakarta, 2015.

Rikardo Simarmata, Mencari Karakter Aksional dalam Pluralisme Hukum, dalam Pluralisme Hukum Sebuah Pendekatan Interdisipliner, $\mathrm{HuMa,}$ Jakarta, 2005.

Soetandyo Wignjosoebroto, Hukum Paradigma, Metode dan Dinamika Masalahnya, Lembaga Studi dan Advokasi Masyarakat (ELSAM) dan Perkumpulan untuk Pembaharuan Hukum Berbasis Masyarakat dan Ekologi (HuMa), Jakarta, 2002.

Yudi Latif, Negara Paripurna, Historisitas, Rasionalitas, dan Aktualitas Pancasila, Gramedia Pustaka Utama, Jakarta, 2011. 